\title{
Statistical Examination of Frost Characterization: A Case of Global Warming Impact in Jordan
}

\author{
Moshrik R. Hamdi ${ }^{1^{*}}$, Mahmoud Abu Alaban ${ }^{2}$, Mohammed Jaber ${ }^{2}$ \\ ${ }^{1}$ Institute of Agricultural Research, Training, Extension and Education, \\ The University of Jordan, Amman, Jordan \\ ${ }^{2}$ Department of Water Management and Environment, The Hashemite University, Zarqa, Jordan \\ E-mail:m.hamdi@ju.edu.jo \\ Received May 11, 2011; revised June 14, 2011; accepted August 29, 2011
}

\begin{abstract}
Radiation and advection frost are common in Jordan as well as other neighboring countries as they face several frost waves each year during the late months of winter. Recently, many frost episodes hit the Jordan Valley and damaged the crops that were compensated by millions of dollars by the Jordanian Government. This manu- script addresses and characterizes frost, and assesses the role of global warming in impacting frost in terms of its frequency, severity, and total number of frost days per year. A comprehensive statistical approach was used. The paper indicates that frost waves will continue to hit in the near future regardless of the fact that Earth is moving towards warmer conditions. Agricultural and financial authorities should be urged to minimize frost damage by considering installing wind fans in Jordan Valley as an active method in addition to implementing good farm practices (as a passive methods where deemed necessary).
\end{abstract}

Keywords: Global Warming, Frost, Jordan, Middle East, Wind Machine, Jordan Valley, Trend Analysis

\section{Introduction}

Jordan is located between $29^{\circ} 10^{\prime} \mathrm{N}-33^{\circ} 45^{\prime} \mathrm{N}$ and $34^{\circ} 55^{\prime}$ E - $39^{\circ} 20^{\prime} \mathrm{E}$, with temperate Mediterranean climate. The northern regions of Jordan show Mediterranean climate that is characterized by long, hot and dry summers and short, cool and wet winters. In contrast, the southern and eastern areas of Jordan are arid. The rainy season extends from late October to early May. Rainfall varies considerably by region from the North-West to the South-East (Figure 1).

The agricultural sector has significant contributions to the national economy of Jordan where it contributes $4.1 \%$ of the GDP at constant prices in 2008 with more than $29 \%$ of indirect contribution. Agriculture generates about $15 \%$ of the total exports and is considered the main source of income for more than 11,000 families who make a living through working in agriculture and live around the poverty line [1].

The Jordan Valley is a vital artery of the agricultural sector in Jordan. Available statistical figures indicate that in 2009 the planted land of this Valley was 32,370 hectares contributing to fifty percent of the national production of main crops. Main crops include vegetables planted over 18,864 hectares; field crops planted over 3,047 hectares and fruit trees planted over 10,459 hectares [1].

Jordan Valley is a primary source of vegetables and citrus products for Jordan, neighboring countries, and to a lesser extent, some European countries. Furthermore, the Valley is the main source of banana production. During winter season, air temperature drops, which prevent vegetable growth or production under normal con-

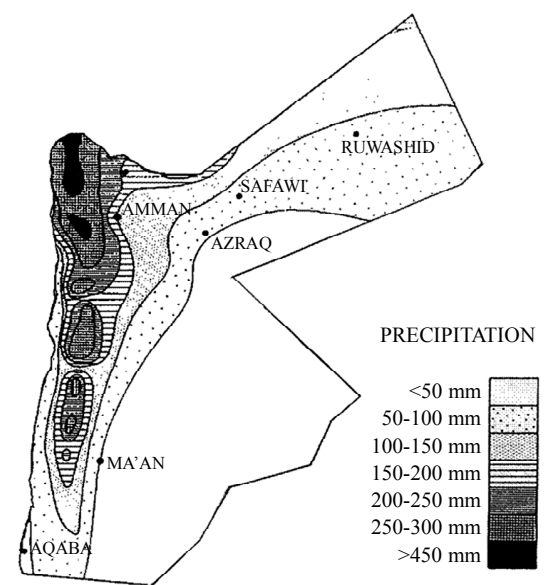

Figure 1. Annual precipitation throughout Jordan [2]. 
ditions. Jordan Valley is unique in its ability to provide a naturally warm atmosphere that enables producing vegetables earlier than most Gulf States and European countries. Nevertheless, the Valley may experience several frost episodes during winter and early spring that could result in massive damage in susceptible crops and have significant enveloping long-term ecological effects which could determine and control plant distribution.

Two types of frost are observed in Jordan; radiation frost and advection frost. Radiation frost is expected when the country is affected by cold polar (cp) that is accompanied by easterly dry-cool wind. Those conditions are attained when the Siberian High extends southward until it reaches the Arabian Peninsula. The impact of the Siberian High is two fold; firstly, cold polar mass that accompanies the high, causes air temperature to drop drastically. Secondly, descending air results in very clear sky and low relative humidity, therefore terrestrial radiation escapes easily to outer space and lead to fast cooling of earth surface and air in contact with it. This condition is ideal for thermal inversion where cold air sinks downward leaving warmer molecules in upper layers. During thermal inversion air temperature could drop to $-6^{\circ} \mathrm{C}$ near ground level, while reported minimum air temperature could be higher than freezing point since the later is measured at about $140 \mathrm{~cm}$ above the ground.

Advection frost may form when Jordan experiences passage of cold air mass or fronts of European origins that accompany Mediterranean cyclones. Advection frost is more destructive than radiation frost as it may last for several days [3].

\subsection{Effect on Plants}

Frost is fatal to plants. The specific temperature for frost injury varies according to the crop and stage of maturity. Cucumber suffers at temperatures below $3{ }^{\circ} \mathrm{C}$. Tender plants, like tomatoes, die when they are exposed to frost. Hardy plants, like radish, tolerate lower temperatures. Peach freezes between -0.6 and $-2.6^{\circ} \mathrm{C}$ [4], and grasses freeze between $-1.5^{\circ} \mathrm{C}$ and $-2.5^{\circ} \mathrm{C}$ [5].

\subsection{Global Warming Impact on Frost Damage}

Global warming is expected to have several climatic impacts and aspects depending on latitude and nearby water bodies. Meehl and colleagues [6] stated that reduced frost frequency does not necessarily mean reduced risk of frost damage. Extreme weather conditions such as floods, droughts, heat waves, and frost are expected to become harsher and to strike more frequently. Consequently, the increase in frost duration and associated agricultural losses in Jordan is being blamed on global cli- mate change. Plants damage usually results from a rapid drop in temperature to below $0^{\circ} \mathrm{C}$ following a mild or warm period if the plants are not fully hardened [7]. Many plant species acclimate to cold over a sustained period in order to withstand freezes. Warmth prevents the acclimation process, therefore sudden drop in air temperature to below $0^{\circ} \mathrm{C}$ causes severe plants damage [8]. A cold spring in 1996 caused little damage to plants across the Eastern United States, but a sudden freeze between the 5th-9th April 2007 has resulted in widespread plants damage because it was preceded by two warm weeks [8].

This paper addresses and characterizes frost, which has been increasingly faced by eastern Mediterranean farmers. Efforts have been made to find out weather global warming is impacting frost in terms of its frequency, severity, and total number of frost days per year.

\section{Materials and Methods}

\subsection{Data Collection}

In studying climate change we needed data about many climate elements like relative humidity, rainfall averages, minimum and maximum air temperature, studying historic climate of the area of Middle East and Jordan, and reviewing previous studies that predicted many changes in climate in Jordan. Available selected meteorological data were retrieved from six different observation weather stations with medium term annual records. Records ranged between 30 to 83 years. The stations are located in different geographical biomes in Jordan. These stations comply by the requirement of the World Metrological Organization regulations [9]. The data sets used in this study were assumed to be collected and reported in a consistent and reliable manner. These data were obtained from Jordanian Department of Meteorology.

Analysis of databases was carried out using different statistical methods depending on the distribution pattern of the characteristics and other specific features.

\subsection{Statistical Analysis}

Statistics was used to analyze and draw meaningful conclusions about characteristics associated with frost and the meteorological data set used in this study. Strict standardization methods selected in this study was required for proper application and interpretation.

In this manuscript both parametric and non-parametric tests were examined whenever appropriate to detect significance, provide evidence of trends, changes, randomness and normality. Trend is a monotonic or step change in the level of the time series. It is preferable to think of 
trend tests as a quantitative basis for deciding whether apparent trends are real [10].

Non-parametric tests make no prior assumption for probability distribution and do not depend upon the form of the underlying distribution of the null hypothesis that meant for testing certain hypothesis. These tests ignore the magnitude of the observations in favor of the relative values or ranks of the data. The tests used to model both linear and non-linear relations, and used for evenly and unevenly spaced observations. Most of these non-parametric methods can work with short series and handle unequally spaced, ties and missing data which are convenient to use in investigations of multiple data sets because exhaustive checking of distributional assumptions is not required.

On the other hand, parametric tests assume that the time series data and the errors follow a normal distribution with homogeneous variance. In general, these tests are more powerful for a given $\mathrm{n}$ when the variable is normally distributed, but much less powerful when it is not, compared with the non-parametric tests [11]. It is widely recognized that non-parametric procedures can have significantly higher power and efficiency than parametric procedures in cases where there is a substantial departure from normality and the large sample size which is commonly encountered in many climate change variables [12].

The dividing line between parametric and non-parametric tests is not a sharp one [13]. All tests used in this research are considered confirmatory data analysis tools to specifically test certain hypotheses. Appropriate parametric tests can overcome some difficulties of series instability that are encountered with the used data.

Although meteorological time series are occasionally not normally distributed and contain properties that are undesirable for use with parametric tests [14], Skewness-Kurtosis Normality test (not affected by ties) was conducted in this study to test all used data for normality. Even for small departures from normality, the performance of the non-parametric procedures is similar to or better than that for the parametric procedures.

Correlating time series afflicted with a trend, or other serial dependencies, may lead to false correlations that do not represent real mechanistic relationships, but occur only owing to the presence of instationarities [15]. Serial correlation affects the test's ability to assess the significance of a trend, which might lead to or increase the possibility of rejection of the null hypothesis of no trend when it is true [16]. Therefore, significance of serial correlation of the time series was evaluated prior to conducting trend analysis.

For detecting trend, both monotonic and step change in the mean or median of the tested data, the critical test statistic value, at $\alpha / 2$ is used (two-sided tail) along with 90, 95, and 99 percent confidence level for evaluating the test hypothesis. Therefore, three parametric and three non-parametric tests were used to determine the possible existence of statistically significant trends, step change in mean/median, and difference in mean/median in two different data periods of the tested meteorological parameters assuming $10 \%, 5 \%$ and $1 \%$ probability levels [17]. Brief descriptions of these statistical tests used in this study are provided by Hamdi et al. [18].

\section{Results and Discussion}

\subsection{Frost and Discussion}

During the seventeenth and eighteenth of December 2004, the country faced a severe frost wave of Siberian origin. Frost lasted for two days and surface temperatures (measured $5 \mathrm{~cm}$ above the soil surface) dropped to below zero. Recorded temperatures ranged between -8 to 2.4 degrees (Figure 2). The frost wave caused severe damage to crops where injury ranged between $10 \%$ to $100 \%$ depending on the type of crop and the region. Thirtyeight thousand acres of which 31 thousand are in the Jordan Valley were injured. The Jordanian cabinet had to allocate JD 1.5 million (about two million USD) to compensate farmers for frost damages.

At the end of the year 2007 and the beginning of the year 2008, Jordan experienced a severe frost wave that affected most parts of the Kingdom. Damages associated with that wave amounted around JD 9.5 million.

In 2008, Jordan experienced two weeks of severe frost episodes starting on 6/1/2008 and ending in 19/1/2008. Unusual low temperatures were recorded. Temperature dropped to $-9^{\circ} \mathrm{C}$ and $-7^{\circ} \mathrm{C}$ in the northern parts and southern parts of Jordan Valley, respectively. Frost cov-

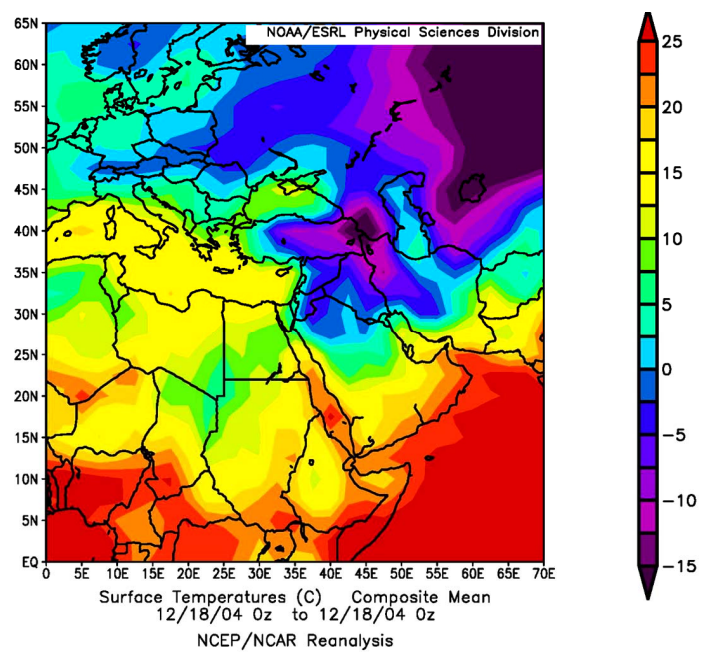

Figure 2. Air Temperature Distribution 18/12/2004 [19]. 
ered all Jordan including Aqaba, a marine city located at the northern part of Aqaba Gulf of the Red Sea and famous of exhibiting warm and sunny winter days. Frost destroyed over 12,000 hectares planted with fruit and vegetables. Jordan Valley, the basket food of Jordan, suffered 90 percent of the damage. Although previous years have witnessed similar frost episodes, that year is unusual in terms of the large geographic area that was affected.

The Jordanian government compensated farmers for losses resulting from this severe frost. Similar losses were reported from neighboring countries including Saudi Arabia, Lebanon, Syria and Israel. Frequent frost is expected to burden the economy in Eastern Mediterranean societies. In addition, frost episodes in the Jordan Valley and the highland is likely to impact food security in the region and Europe, which depends partly on imported vegetables and fruit produced in Jordan Valley.

Although frost is common in the desert, which covers more than $90 \%$ of Jordan, it is less common in the northern parts of Jordan Valley and rare in southern parts of Jordan Valley and Wadi Araba. Jordan Valley is considered the food basket because most vegetables, citruses and several fruit are produced therein. Winter Frost destroys large cultivated areas and drastically reduces the yields of many crops. During frost episodes, markets experience severe shortages of essential products, mainly banana, tomatoes, cucumber, squash, zucchini, eggplant, lettuce, green pepper, and herbs.

\subsection{Synoptic Conditions Associated with Frost}

Climate in Jordan and eastern Mediterranean region is influenced by the Siberian High, Azores High, and the Indian Monsoon Cyclone. In addition, climate exhibits spatial variation based on local topography. During winter, polar air masses of European origin sweep across the Mediterranean and enter the region from the northwest twice a month [20].

The Siberian Anticyclone is a semi-permanent system of high atmospheric pressure centered in northeastern Siberia during the colder half of the year. It may block or reduce the size of low-pressure cells or cyclones and generate dry weather across Eastern Mediterranean landscapes. During winter the earth surface becomes extremely cold in upper latitudes in the Northern hemisphere and as a result, the Siberian High intensifies and covers immense areas until it reaches the southern-eastern part of Asia. A ridge extends all the way to the Arabian Peninsula. This ridge blocks Mediterranean cyclones from reaching into eastern Mediterranean areas particularly Jordan (Figure 3). During those conditions Jordan experiences easterly or north-easterly cool-dry wind (Fig- ure 4). Because of high pressures, there will be active downdrafts (descending air), which lead to clear sky and therefore temperature may drop to below freezing point during night. These conditions are favorable for frost formation in the eastern desert, the western mountains, and northern parts of the Jordan Valley [2].

The Azores High is a large subtropical semi-permanent center of high atmospheric pressure found near the Azores in the Atlantic Ocean, at the Horse latitudes. The system influences the weather and climatic patterns of vast areas of North Africa and Europe. The aridity of the Sahara Desert and Mediterranean Basin is due to the subsidence of air in the system. In the summer, the central pressure lays around 1024 mbar, and moves north towards the Iberian Peninsula, causing ridging acrossFrance, northern Germany and the southeastern parts of

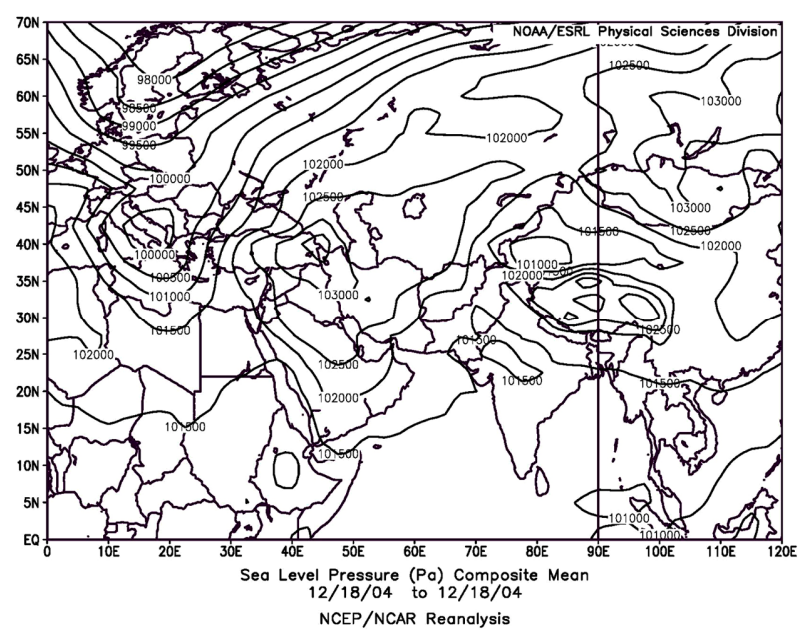

Figure 3. Sea level Pressure 18/12/2004 [19].

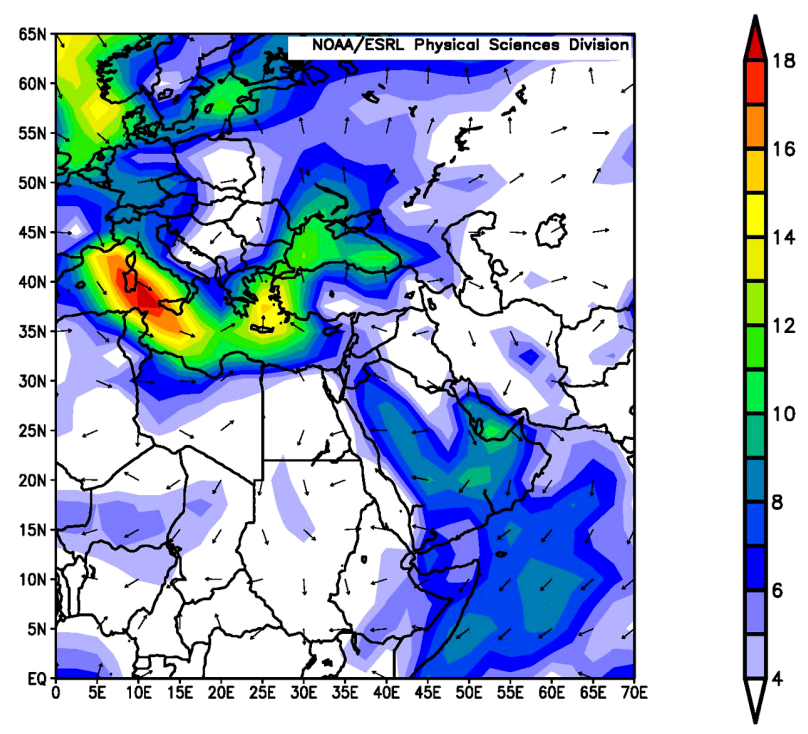

Figure 4. Wind Distribution 18/12/2004 [19]. 
the United Kingdom. During winter, the Azores High intensifies and extends to cover most of the Western and high by High and northern part of Africa. If the Azores High and the Siberian High intersect, they would form a high pressure band that extends all the way to Anatolia and North Africa. During this condition, air temperature increases in the whole region and clear skies dominate in the region. If the center of the Azores High moves northeast and situates above Iberian Island, it forces polar cool wind to circulate around its center and enters the Mediterranean as a strong jet stream which stimulates forming and intensifying Mediterranean cyclones. If this condition coincides with the presence of upper trough in the region, then cool air continues to flow in, and thereby intensify the cyclones further. Normally, those cyclones move to east or north east Mediterranean. This condition is ideal for precipitation in northern parts of Jordan [3].

The Indian monsoon impacts vast area of Iran, Arabian Peninsula, and the Middle East during summer months therefore it is not likely to have impacts on frost formation in Eastern Mediterranean stats.

\subsection{Global Warming Impact on Frost}

The fact that the Earth is experiencing global warming has been proven by several studies. The Fourth Assessment Report of the Intergovernmental Panel on Climate Change (IPCC), issued in 2007 pointed out that average Earth temperatures around the world have increased 0.8 ${ }^{\circ} \mathrm{C}$ since 1880 , and ten of the past 12 years are among the warmest since 1850 [21]. However, it is unknown how global warming is affecting frost characteristics. In this section, frost data from five stations (Baqoura, Irbid, Al-Khalidiah, Al-Rebah and Al-Shoubek) are analyzed to detect any increasing or decreasing trends in the frost characteristics including grass temperature, frost duration, and number of frost days. Results are summarized in Tables 1-5.

As we learn from Table 1, there is no clear trend, but there is a slight decrease in number of frost days and a slight increase in grass temperature at Baqoura, a town in northern part of Jordan Valley. In Irbid, data do not show a clear increasing or decreasing trend (Table 2). At Al-Khalidiah, a town located at the edge of the desert to the east from Irbid, grass temperature decreased while the number of frost days increased (Table 3). At AlRebah, minimum and average grass temperatures did not exhibit a clear trend, however, the number of frost days during February increased (Table 4). At Al-Shoubek, minimum and average grass temperatures have increased since 1984, but number of frost days does not show significant change (Table 5).

\section{Summary, Conclusions and Mitigation}

Jordan as well as neighboring East-Mediterranean countries faces several frost waves each year. A frost wave may last for several days and may result in severe damage to crops. In Jordan, farmers often protect their crops either by using heaters or by operating sprinklers. Plastic tunnels are also used to protect crops from early autumn frost. In elevated areas, farmers avoid planting during

Table 1. Temporal variation of frost at Baqoura.

\begin{tabular}{|c|c|c|c|c|c|c|c|c|c|}
\hline \multirow{3}{*}{$\begin{array}{c}\text { Test } \\
\text { Period } \\
\text { Tested } \\
\text { Parameter }\end{array}$} & \multicolumn{9}{|c|}{ Baqoura } \\
\hline & \multicolumn{3}{|c|}{ Overall } & \multicolumn{3}{|c|}{ January } & \multicolumn{3}{|c|}{ February } \\
\hline & $\begin{array}{c}\text { Min Grass } \\
\text { Temp }\end{array}$ & $\begin{array}{c}\text { Average } \\
\text { Grass Temp }\end{array}$ & $\begin{array}{l}\text { Number of } \\
\text { Frost Days }\end{array}$ & $\begin{array}{c}\text { Min Grass } \\
\text { Temp }\end{array}$ & $\begin{array}{c}\text { Average Grass } \\
\text { Temp }\end{array}$ & $\begin{array}{l}\text { Number of } \\
\text { Frost Days }\end{array}$ & $\begin{array}{c}\text { Min Grass } \\
\text { Temp }\end{array}$ & $\begin{array}{c}\text { Average } \\
\text { Grass Temp }\end{array}$ & $\begin{array}{l}\text { Number of } \\
\text { Frost Days }\end{array}$ \\
\hline Mann-Kendall & NS & $90+$ & NS & NS & NS & $95-$ & NS & NS & NS \\
\hline $\begin{array}{c}\text { Linear } \\
\text { Regression }\end{array}$ & NS & NS & NS & NS & NS & NS & NS & NS & NS \\
\hline Cusum $^{\text {a }}$ (CS) & 90 & & NS & 99 & NS & 90 & 99 & NS & NS \\
\hline $\begin{array}{l}\text { CS Year of } \\
\text { Change }\end{array}$ & 2000 & 1999 & - & 1999 & - & 2007 & 1999 & - & - \\
\hline $\begin{array}{c}\text { Worsley } \\
\text { Likelihood (WL) }\end{array}$ & NS & $\begin{array}{c}\text { Mean71-07< } \\
07-08 @ 90\end{array}$ & NS & $\begin{array}{c}\text { Mean72-07< } \\
07-08 @ 90\end{array}$ & $\begin{array}{c}\text { Mean72-74< } \\
\text { 74-08@95 }\end{array}$ & $\begin{array}{c}\text { Mean72-07 < } \\
07-08 @ 90\end{array}$ & $\begin{array}{c}\text { Mean72-99< } \\
99-08 @ 95\end{array}$ & NS & NS \\
\hline $\begin{array}{l}\text { WL Year of } \\
\text { Change }\end{array}$ & - & 2007 & & 2007 & 1974 & 2007 & 1999 & - & - \\
\hline Rank Sum & NS & NS & NS & NS & NS & NS & $\begin{array}{l}\text { Median72-89 } \\
<90-08 @ 95\end{array}$ & NS & NS \\
\hline Student's t & NS & NS & NS & NS & NS & NS & $\begin{array}{c}\text { Mean72-89< } \\
90-08 @ 95\end{array}$ & NS & NS \\
\hline
\end{tabular}


Table 2. Temporal variation of frost at Irbid.

\begin{tabular}{|c|c|c|c|c|c|c|c|c|c|}
\hline \multirow{3}{*}{$\begin{array}{c}\text { Test } \\
\text { Period } \\
\text { Tested } \\
\text { Parameter }\end{array}$} & \multicolumn{9}{|c|}{ Irbid } \\
\hline & \multicolumn{3}{|c|}{ Overall } & \multicolumn{3}{|c|}{ January } & \multicolumn{3}{|c|}{ February } \\
\hline & $\begin{array}{c}\text { Min } \\
\text { Grass Temp }\end{array}$ & $\begin{array}{c}\text { Average } \\
\text { Grass Temp }\end{array}$ & $\begin{array}{l}\text { Number of } \\
\text { Frost Days }\end{array}$ & $\begin{array}{c}\text { Min Grass } \\
\text { Temp }\end{array}$ & $\begin{array}{c}\text { Average } \\
\text { Grass Temp }\end{array}$ & $\begin{array}{l}\text { Number of } \\
\text { Frost Days }\end{array}$ & $\begin{array}{c}\text { Min Grass } \\
\text { Temp }\end{array}$ & $\begin{array}{c}\text { Average } \\
\text { Grass Temp }\end{array}$ & $\begin{array}{l}\text { Number of } \\
\text { Frost Days }\end{array}$ \\
\hline $\begin{array}{l}\text { Mann- } \\
\text { Kendall }\end{array}$ & NS & NS & NS & NS & NS & NS & NS & NS & NS \\
\hline $\begin{array}{c}\text { Linear } \\
\text { Regression }\end{array}$ & $90-$ & NS & NS & NS & NS & NS & NS & NS & NS \\
\hline Cusum $^{\text {a }}$ (CS) & NS & NS & NS & NS & NS & 95 & NS & NS & NS \\
\hline $\begin{array}{l}\text { CS Year } \\
\text { of Change }\end{array}$ & - & - & - & - & - & 2004 & - & - & - \\
\hline $\begin{array}{l}\text { Worsley } \\
\text { Likelihood } \\
\text { (WL) }\end{array}$ & $\begin{array}{c}\text { Mean03-08< } \\
67-03 @ 90\end{array}$ & $\begin{array}{c}\text { Mean07-08 < } \\
67-07 @ 95\end{array}$ & NS & $\begin{array}{c}\text { Mean07-08< } \\
67-07 @ 95\end{array}$ & $\begin{array}{c}\text { Mean07-08< } \\
67-07 @ 99\end{array}$ & NS & NS & NS & NS \\
\hline $\begin{array}{l}\text { WL Year } \\
\text { of Change }\end{array}$ & 2003 & 2007 & - & 2007 & 2007 & - & - & - & - \\
\hline Rank Sum & $\begin{array}{c}\text { Median88-08< } \\
67-87 @ 95\end{array}$ & NS & $\begin{array}{c}\text { Median88-08 }< \\
67-87 @ 95\end{array}$ & NS & NS & $\begin{array}{c}\text { Median88-08 } \\
<67-87 @ 95\end{array}$ & NS & NS & $\begin{array}{c}\text { Median88-08< } \\
67-87 @ 95\end{array}$ \\
\hline Student's t & $\begin{array}{c}\text { Mean88-08< } \\
67-87 @ 95\end{array}$ & NS & $\begin{array}{c}\text { Mean88-08< } \\
67-87 @ 95\end{array}$ & NS & NS & NS & $\begin{array}{l}\text { Mean88-08 } \\
<67-87 @ 90\end{array}$ & NS & NS \\
\hline
\end{tabular}

Table 3. Temporal variation of frost at Al-Khalidiah.

\begin{tabular}{|c|c|c|c|c|c|c|c|c|c|}
\hline \multirow{3}{*}{$\begin{array}{c}\text { Test } \\
\text { Period } \\
\text { Tested Parameter }\end{array}$} & \multicolumn{9}{|c|}{ Al-Khalidiah } \\
\hline & \multicolumn{3}{|c|}{ Overall } & \multicolumn{3}{|c|}{ January } & \multicolumn{3}{|c|}{ February } \\
\hline & $\begin{array}{l}\text { Min Grass } \\
\text { Temp }\end{array}$ & $\begin{array}{c}\text { Average } \\
\text { Grass Temp }\end{array}$ & $\begin{array}{l}\text { Number of } \\
\text { Frost Days }\end{array}$ & $\begin{array}{c}\text { Min Grass } \\
\text { Temp }\end{array}$ & $\begin{array}{c}\text { Average } \\
\text { Grass Temp }\end{array}$ & $\begin{array}{l}\text { Number of } \\
\text { Frost Days }\end{array}$ & $\begin{array}{c}\text { Min Grass } \\
\text { Temp }\end{array}$ & $\begin{array}{c}\text { Average } \\
\text { Grass Temp }\end{array}$ & $\begin{array}{l}\text { Number of } \\
\text { Frost Days }\end{array}$ \\
\hline Mann-Kendall & $90-$ & 95- & NS & NS & NS & NS & NS & NS & NS \\
\hline Linear Regression & NS & $99-$ & $95^{+}$ & NS & NS & NS & NS & $90-$ & NS \\
\hline Cusum $^{\mathrm{a}}$ (CS) & NS & NS & NS & NS & NS & NS & NS & 95 & 99 years) \\
\hline $\begin{array}{c}\text { CS Year of } \\
\text { Change }\end{array}$ & - & - & - & - & - & - & - & 2002 & 1996 \\
\hline $\begin{array}{l}\text { Worsley Likeli- } \\
\text { hood (WL) }\end{array}$ & NS & $\begin{array}{c}\text { Mean69-08< } \\
67-69 @ 95\end{array}$ & $\begin{array}{c}\text { Mean67-70< } \\
70-08 @ 99\end{array}$ & NS & NS & NS & NS & $\begin{array}{c}\text { Mean68-70< } \\
70-08 @ 90\end{array}$ & NS \\
\hline $\begin{array}{l}\text { WL Year of } \\
\text { Change }\end{array}$ & - & 1969 & 1970 & - & - & - & - & 1970 & - \\
\hline Rank Sum & NS & NS & $\begin{array}{c}\text { Median88-08 < } \\
67-87 @ 90\end{array}$ & NS & NS & NS & NS & NS & 95 \\
\hline Student's t & NS & NS & $\begin{array}{c}\text { Mean67-87< } \\
88-08 @ 90\end{array}$ & NS & NS & NS & NS & NS & NS \\
\hline
\end{tabular}

frost-prone periods or using plastic tunnels to protect their farms.

The Jordanian government has pledged to compensate farmers for frost damages. Governmental compensation puts extra load on the local budget especially in a country with few resources.

The findings of this study indicate that frost waves will continue to hit in near future regardless of the fact that Earth is moving towards warmer conditions. Local governments are expected to spend more money in com- pensation for crops damages caused by the frost. Previous compensation schemes have been proven to be inefficient. Agricultural and financial authorities need to take courage and wise steps to minimize frost damage. Among the things that governments are invited to consider is installing wind machines in Jordan Rift Valley and other frost-prone regions. The fans are used to protect crops against cold injury at winter, spring's late frost and autumn's early frost. Wind fans will pay off their cost within few years and will help sustaining secure 
Table 4. Temporal variation of frost at Al-Rebah.

\begin{tabular}{|c|c|c|c|c|c|c|c|c|c|}
\hline \multirow{3}{*}{$\begin{array}{c}\text { Test } \\
\text { Period } \\
\text { Tested } \\
\text { Parameter }\end{array}$} & \multicolumn{9}{|c|}{ Al-Rebah } \\
\hline & \multicolumn{3}{|c|}{ Overall } & \multicolumn{3}{|c|}{ January } & \multicolumn{3}{|c|}{ February } \\
\hline & $\begin{array}{c}\text { Min Grass } \\
\text { Temp }\end{array}$ & $\begin{array}{c}\text { Average } \\
\text { Grass Temp }\end{array}$ & $\begin{array}{l}\text { Number of } \\
\text { Frost Days }\end{array}$ & $\begin{array}{c}\text { Min Grass } \\
\text { Temp }\end{array}$ & $\begin{array}{c}\text { Average } \\
\text { Grass Temp }\end{array}$ & $\begin{array}{l}\text { Number of } \\
\text { Frost Days }\end{array}$ & $\begin{array}{c}\text { Min Grass } \\
\text { Temp }\end{array}$ & $\begin{array}{c}\text { Average } \\
\text { Grass Temp }\end{array}$ & $\begin{array}{l}\text { Number of } \\
\text { Frost Days }\end{array}$ \\
\hline Mann-Kendall & NS & NS & $90+$ & NS & NS & NS & NS & NS & $95+$ \\
\hline $\begin{array}{c}\text { Linear } \\
\text { Regression }\end{array}$ & NS & NS & $90+$ & NS & NS & NS & NS & NS & NS \\
\hline Cusum $^{a}$ (CS) & NS & NS & 95 & NS & NS & NS & NS & NS & 95 \\
\hline $\begin{array}{l}\text { CS Year } \\
\text { of Change }\end{array}$ & - & - & 1988 & - & - & - & - & - & 1988 \\
\hline $\begin{array}{l}\text { Worsley } \\
\text { Likelihood } \\
\text { (WL) }\end{array}$ & NS & NS & $\begin{array}{c}\text { Mean68-80< } \\
80-08 @ 99\end{array}$ & NS & NS & NS & NS & NS & NS \\
\hline $\begin{array}{l}\text { WL Year } \\
\text { of Change }\end{array}$ & - & - & 1980 & - & - & - & - & - & - \\
\hline Rank Sum & NS & NS & $\begin{array}{c}\text { Median68-87 } \\
<88-08 @ 95\end{array}$ & NS & NS & NS & NS & NS & $\begin{array}{l}\text { Median89-08 } \\
<69-88 @ 99\end{array}$ \\
\hline Student's t & NS & NS & $\begin{array}{c}\text { Mean68-87< } \\
88-08 @ 90\end{array}$ & NS & NS & NS & NS & NS & $\begin{array}{c}\text { Mean69-88< } \\
\text { 89-08@95 }\end{array}$ \\
\hline
\end{tabular}

Table 5. Temporal variation of frost at Al-Shoubek.

\begin{tabular}{|c|c|c|c|c|c|c|c|c|c|}
\hline \multirow{3}{*}{$\begin{array}{c}\text { Test } \\
\text { Period } \\
\text { Tested } \\
\text { Parameter }\end{array}$} & \multicolumn{9}{|c|}{ Al-Shoubek } \\
\hline & \multicolumn{3}{|c|}{ Overall } & \multicolumn{3}{|c|}{ January } & \multicolumn{3}{|c|}{ February } \\
\hline & $\begin{array}{c}\text { Min Grass } \\
\text { Temp }\end{array}$ & $\begin{array}{c}\text { Average } \\
\text { Grass Temp }\end{array}$ & $\begin{array}{l}\text { Number of } \\
\text { Frost Days }\end{array}$ & $\begin{array}{l}\text { Min Grass } \\
\text { Temp }\end{array}$ & $\begin{array}{c}\text { Average Grass } \\
\text { Temp }\end{array}$ & $\begin{array}{l}\text { Number of } \\
\text { Frost Days }\end{array}$ & $\begin{array}{l}\text { Min Grass } \\
\text { Temp }\end{array}$ & $\begin{array}{c}\text { Average } \\
\text { Grass Temp }\end{array}$ & $\begin{array}{l}\text { Number of } \\
\text { Frost Days }\end{array}$ \\
\hline Mann-Kendall & NS & NS & NS & NS & $95^{+}$ & NS & $95^{+}$ & $95^{+}$ & NS \\
\hline $\begin{array}{c}\text { Linear } \\
\text { Regression }\end{array}$ & NS & NS & NS & NS & $90^{+}$ & NS & $90^{+}$ & $90^{+}$ & NS \\
\hline Cusum $^{\mathrm{a}}$ (CS) & NS & 99 & NS & NS & $90^{+}$ & NS & NS & 95 & 99 \\
\hline $\begin{array}{l}\text { CS Year of } \\
\text { Change }\end{array}$ & - & 1984 & - & - & 1984 & - & - & 1984 & 2007 \\
\hline $\begin{array}{c}\text { Worsley } \\
\text { Likelihood (WL) }\end{array}$ & NS & NS & 99 & NS & NS & NS & NS & NS & NS \\
\hline $\begin{array}{l}\text { WL Year } \\
\text { of Change }\end{array}$ & - & - & 1966 & - & - & - & - & - & - \\
\hline Rank Sum & NS & 95 & NS & NS & $\begin{array}{c}\text { Median88-08 }< \\
67-87 @ 90\end{array}$ & NS & $\begin{array}{r}\text { Median66-86 } \\
87-08 @ 95\end{array}$ & $\begin{array}{c}\text { Median66-86< } \\
87-08 @ 95\end{array}$ & NS \\
\hline Student's t & NS & 99 & NS & NS & $\begin{array}{c}\text { Mean67-87< } \\
88-08 @ 90\end{array}$ & NS & NS & NS & NS \\
\hline
\end{tabular}

NS: non-significant at least $\alpha=0.1,{ }^{+}$increasing trend at specified alpha, - decreasing trend at specified alpha, ${ }^{\text {a }}$ data in later years are higher than earlier years at specified alph

source of food for those who depend on the products of the Jordan Rift Valley. A delayed growing season will cause Jordan to lose its advantage over countries in colder climates in early exports of vegetables and fruits.

\section{References}

[1] Department of Statistics (DoS), "Agricultural Statistics," Internal Report, Amman, 2009.
[2] M. Al-Jaloudy, "Jordan Profile, the Food and Agriculture Organization (FAO)," 2001. http://www.fao.org/ag/AGP/agpc/doc/Counprof/Jordan/J ordan.htm

[3] N. A. Shehadeh, "Climate of Jordan," Dar Al-Bashir, Amman, 1991.

[4] E. N. Ashworth and G. A. Davis, "Ice Formation in Woody Plants under Field Conditions," HortScience, Vol. 21, No. 5, 1986, pp 1233-1234. 
[5] R. S. Pearce, M. P. Fuller, "Freezing of Barley (Hordeum) Studied by Infrared Video Thermography," Plant Physiology, Vol. 125, 2001, pp. 227-240. doi:10.1104/pp.125.1.227

[6] G. A. Meehl, et al. "An Introduction to Trends in Extreme Weather and Climate Events: Observations, Socioeconomic Impacts, Terrestrial Ecological Impacts, and Model Projections", Bulletin of the American Meteorological Society, Vol. 81, No. 3, 2000, pp. 413-416. doi:10.1175/1520-0477(2000)081<0413:AITTIE $>2.3$.CO $\underline{i 2}$

[7] A. M. Jo“nsson, M. L. Linderson, I. Stjernquist, P. Schlyter and L. Ba"rring, "Will Climate Change Increase the Frequency of Temperature Backlashes Causing Frost Damage in Swedish Forests?" Geophysical Research Abstracts, EGS-AGU-EUG Joint Assembly, Nice, Vol. 5, 6-11 April 2003, No. 01010, 2003.

[8] L. Gu, P. J. Hanson, W. M. Post, D. P. Kaiser and B. Yang, "The 2007 Eastern US Spring Freeze: Increased Cold Damage in a Warming World," BioScience, Vol. 58, No. 3, 2008, pp. 253-262. doi:10.1641/B580311

[9] World Meteorological Organization (WMO), "Guide to Hydrological Practices,” No. 168, Geneva, 1974.

[10] J. C. Loftis, R.C. Ward, R. D. Phillips and C. Tayler, "An Evaluation of Trend Detection Techniques for Use in Water Quality Monitoring Programs," U.S. Environmental Protection Agency, Office of Acid Deposition Environmental Monitoring and Quality Assurance, Washington, D.C., EPA/600/3-89/037, 1989.

[11] R. M. Hirsch, R. B. Alexander and R. A. Smith, "Selection of Methods for the Detection and Estimation of Trends in Water Quality," Water Resources Research, Vol. 27, No. 5, 1991, pp. 803-813. doi:10.1029/91WR00259

[12] D. R. Helsel and R. M. Hirsch, "Discussion of Applicability of the T-Test for Detecting Trends in Water Quality Variables," In: R. H. Montgomery and J. C. Loftis, Eds., Water Resources Bulletin, Vol. 24, No. 1, pp. 201-204,
1988.

[13] W. H. Kruskal and J. M. Tanur, Eds., "International Encyclopedia of Statistics," 2nd Edition, Free Press, New York, 1978.

[14] R. M. Hirsch and J. R. Slack, "Non-Parametric Trend Test for Seasonal Data with Serial Dependence," Water Resources Research, Vol. 20, No. 4, 1984, pp. 727-732. doi:10.1029/WR020i006p00727

[15] C. Chatfield, "The Analysis of Time Series: An Introduction," 6th Edition, Chapman and Hall, London, 2004.

[16] S. Yue, P. J. Pilon and B. Phinney, "Canadian Streamflow Trend Detection: Impacts of Serial and Cross Correlation," Hydrological Science Journal, Vol. 48, No. 1, pp. 51-64. doi:10.1623/hysj.48.1.51.43478

[17] Chr. Goossens and A. Berger, "Annual and Seasonal Climatic Variations of Northern Hemisphere and Europe over the Last Century," Annales Geophysicae, Vol. 4, No. 4, 1986, pp. 385-400.

[18] M. R. Hamdi, M. Abu-Allaban, A. Elshaieb, M. Jaber and N. M. Momani, "Climate Change in Jordan: A Comprehensive Examination Approach," American Journal of Environmental Sciences, Vol. 5, No. 1, 2009, pp. 58-68. doi;10.3844/ajessp.2009.58.68

[19] Earth System Research Laboratory, "ESRL Physical Sciences Division Programs," 2011. http://www.esrl.noaa.gov/psd/programs/

[20] U. Dayan, B. Ziv, T. Shoob and Y. Enzel, "Suspended Dust over Southeastern Mediterranean and Its Relation to Atmospheric Circulations," International Journal of Climatology, Vol. 28, No. 7, 2008, pp. 915-924. doi:10.1002/joc. 1587

[21] IPCC Fourth Assessment, Science, Intergovernmental Panel on Climate Change, "Climate Change 2007: The Physical Science Basis," Contribution of Working Group I to the Fourth Assessment Report of the IPCC, Cambridge University Press, New York, 2007. http://ipcc-wg1.ucar.edu/wg1/wg1-report.html. 